\title{
Calculation of Area and Volume for North Part of Great Salt Lake, Utah
}

Prepared in cooperation with the Utah Department of Natural Resources, Division of Forestry, Fire, and State Lands

\section{By Robert L. Baskin}

\section{Abstract}

The U.S. Geological Survey, in cooperation with the Utah Department of Natural Resources, Division of Forestry, Fire, and State Lands, collected bathymetric data for the north part of Great Salt Lake during the spring and early summer of 2006 using a single-beam, highdefinition fathometer and real-time differential global positioning system. About 5.2 million depth measurements were collected along more than 765 miles $(1,230$ kilometers) of survey transects. Sound-velocity profiles were obtained in conjunction with the bathymetric data to provide time-of-travel corrections to the depth calculations. Data were processed with commercial hydrographic software and exported into geographic information system (GIS) software for mapping and calculation of area and volume. Area and volume calculations show a maximum area of about 385,000 acres (1,560 square kilometers) and a maximum volume of about 5,693,000 acre-feet (about 7 cubic kilometers) at a water-surface altitude of 4,200 feet (1,280 meters). Minimum natural water-surface altitude of the north part of Great Salt Lake is just below 4,167 feet $(1,270$ meters) in the area just north of the Union Pacific railroad causeway halfway between Saline and the western edge of the lake. The north part of Great Salt Lake generally grades gradually to the west and north and is bounded by steep scarps along its eastern border. Calculations for area and volume are based on a low altitude of 4,167 feet $(1,270$ meters) to a high altitude of 4,200 feet $(1,280$ meters).

\section{Introduction}

Prior to the 1980s, detailed information about many aspects of Great Salt Lake, including bathymetric data, was scarce. Flooding in the early 1980s increased concern for avian resources and the lake ecosystem, and the emergence of the brine shrimp industry created both public interest and management concern. To fill the need for a better understanding of the physical characteristics of the lake, the U.S. Geological Survey (USGS), in cooperation with the Utah Department of Natural Resources, Division of Forestry, Fire, and State Lands, collected bathymetric data for the north part of Great Salt Lake (fig. 1) during the spring and early summer of 2006 using a single-beam, high-definition fathometer and real-time differential global positioning system. These data were collected to better define the physical characteristics of the north part of the lake, provide data for improved calculations of area and volume, and provide lake-bottom contour information that could be used in future efforts to develop a general circulation model of the lake. Data-collection methods and quality-control restrictions were identical to those used for generation of the bathymetric map for the south part of Great Salt Lake (Baskin and Allen, 2005) and the resulting south part area/volume table (Baskin, 2005).

About 5.2 million depth measurements were collected along more than 765 miles (1,230 kilometers) of survey

transects (fig. 2) during the data-collection phase of this study. Sound-

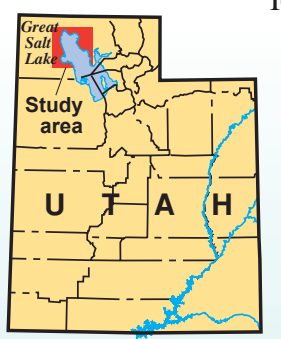
velocity profiles were obtained in conjunction with the bathymetric data to provide time-of-travel corrections to the depth calculations. Data were processed with commercial hydrographic

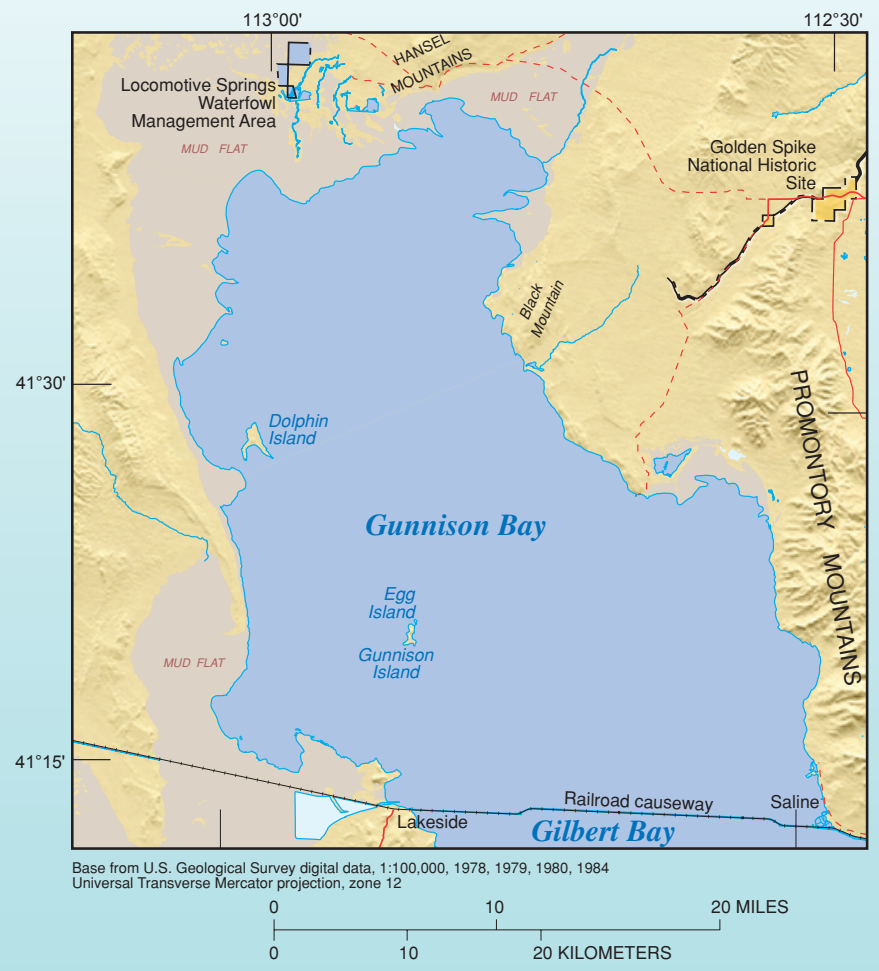

Figure 1. Map showing north part of Great Salt Lake and vicinity, Utah. 
software and exported into geographic information system (GIS) software for mapping and calculation of area and volume. Because of the shallow nature of the lake and the limitations of the instrumentation, contours above an altitude of 4,194 feet (1,278 meters) were digitized from existing USGS 1:24,000-scale topographic maps. A triangulated irregular network generated from the bathymetric data and digitized contours was used for the calculations of area and volume. This report describes the methods and data used to calculate the area and volume of the north part of Great Salt Lake at 0.5-foot intervals from an altitude of 4,167 feet (1,270 meters) to 4,200 feet (1,280 meters).

\section{Description of Study Area}

Great Salt Lake is a terminal lake in the northwestern part of Utah; changes in water-surface altitude are determined by differences between net inflow and evaporation from the surface of the lake. Inflow to the lake is affected by impoundments on and diversions from streams that flow into the lake. At a water-surface altitude of 4,200 feet $(1,280$ meters), the lake has a surface area of about 1,660 square miles (4,300 square kilometers) and an average depth of 14.6 feet (4.45 meters). In 1963, Great Salt Lake was at its lowest water-surface altitude in recent history (about 4,191 feet [1,277 meters]), covered about 950 square miles (2,460 square kilometers), and had a maximum depth of about 25 feet (7.6 meters). In 1986, Great Salt Lake was at its highest water-surface altitude in recent history (about 4,212 feet [1,284 meters]), covered about 2,400 square

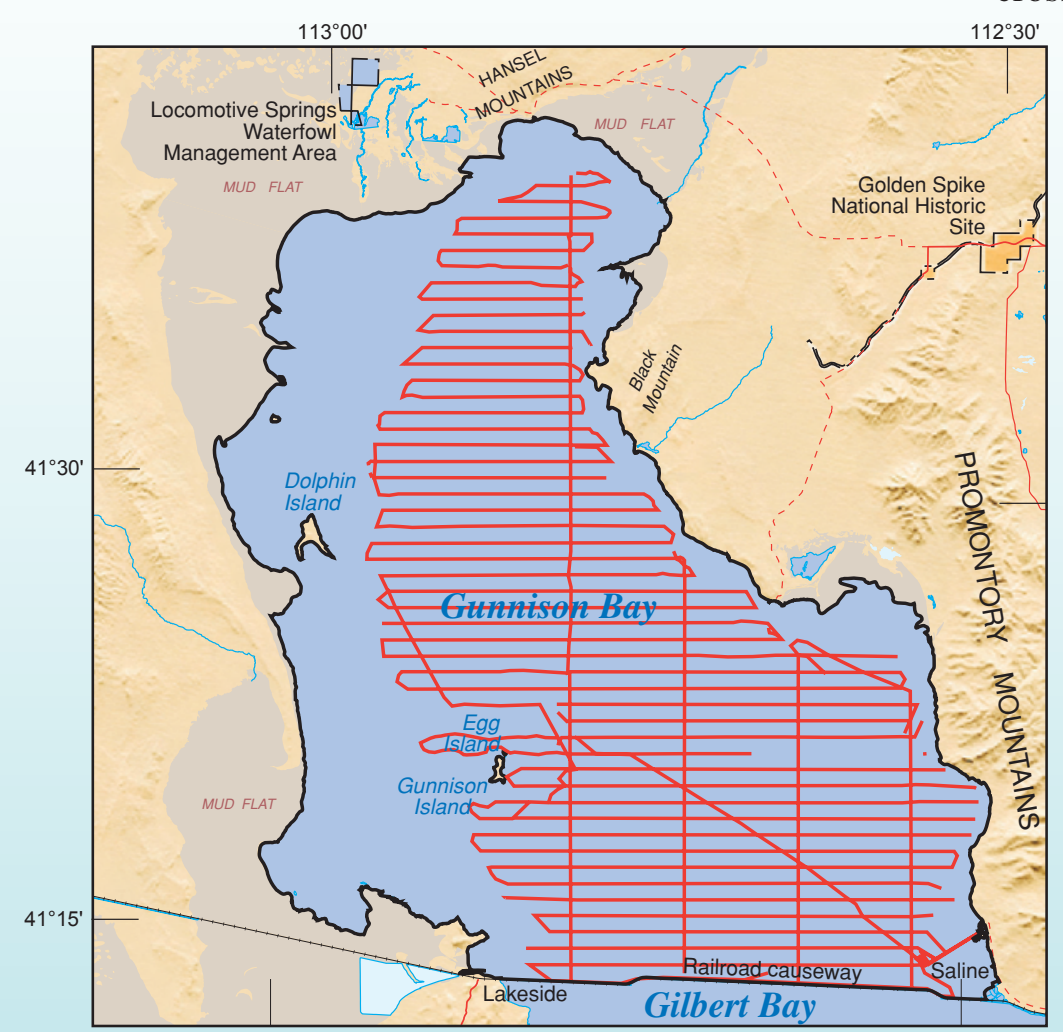
Base from U.S. Geological Survey digital data, 1:100,000, 1978, 1979, 1980, 1984
Universal Transverse Mercator projection, zone 12
0
$0 \quad 10$
10
20 MILES
20 KILOMETERS

Figure 2. Map showing location of survey transects and boundary of area used in area and volume calculations for north part of Great Salt Lake, Utah. miles (6,216 square kilometers), and had a maximum depth of about 45 feet (13.7 meters). The area of the lake surveyed and used for these calculations includes that part of the lake north of the Union Pacific railroad causeway and includes areas of impoundment near the southwest and southeast corners of the lake up to the 4,200-foot contour (fig. 2). Maximum altitude used in the calculation of area and volume in this report is 4,200 feet (1,280 meters).

\section{Methods}

\section{Data Collection}

Bathymetric data were collected over the navigable areas of the north part of Great Salt Lake during the spring and early summer of 2006. An automated system consisting of a digital and analog (paper chart) single-beam fathometer coupled to a real-time, differentially corrected global positioning system with the data logged into a navigational computer was used for the basic position/depth data collection. Depths were derived indirectly by measuring the time required for a sonar signal to travel from the transmitter to the bottom of the lake and back to a receiver. Measured sound velocities were used to calculate corrections to the basic time-of-travel data and provide a velocity-corrected distance between the transmitter and receiver. Distance from lake surface to the transceiver face was measured and added to the distance between the transducer and lake bottom to derive the calculated depth of the lake. Analog paper records were collected during the survey for all transects to cross-check digital readings and provide detail of bottom features during the collection of field data.

About 765 miles (1,230 kilometers) of transects were collected primarily on east-west transects spaced about 0.62 miles ( 1 kilometer) apart and included five north-south transects (fig. 2). Position data were recorded at about a 1-second rate and depth data at about 10 points per second. Vessel speed was limited to less than about 10 miles per hour (16 kilometers per hour) to maximize the number of depth measurements gathered during the data-collection phase. Quality-control considerations limited the periods of data collection to times when the lake surface had minimal swell and wave height generally was less than 6 inches $(0.15$ meter). Because of the high sound velocity (a result of the higher-density water) and limitations in the instrumentation, data collection was limited to areas deeper than about 3 feet (1 meter).

Water depth was measured with a survey-grade Reson, Inc. ${ }^{1}$, model 210 , single-beam echosounder using a 2.7-degree beam width, 200-kilohertz transducer. Manufacturer specifications for this echosounder indicate that the depth of operation is from 0.2 to 600 meters ( 0.7 to 1,969 feet) and that the depth-measurement accuracy is 1 centimeter $(0.4$ inch) at depths of less than 100 meters. Speed of

\footnotetext{
1 Use of trade names in this report is for identification purposes only and does not constitute endorsement by the U.S Geological Survey.
} 
sound for the data-collection segment of this survey was set at a constant 1,600 meters per second (5,250 feet per second). Speed-of-sound corrections were subsequently applied during data processing.

Sound-velocity profiles were collected at several times and locations throughout the survey at 1-meter (3.28-foot) vertical intervals with a direct "time-of-flight" soundvelocity sensor. The sound-velocity sensor used during this investigation was accurate to plus or minus 0.25 meter per second (0.8-foot-per-second) in water with a 0.2 -meter-persecond (0.7-foot-per-second) resolution. Measured sound velocities ranged from 1,788 meters per second to 1,804 meters per second. These data were written into soundvelocity correction files and used during data processing.

Horizontal position data (latitude and longitude) were obtained with a Trimble AG132 integrated Global Positioning System (GPS)/ Differential Global Positioning System (DGPS) coupled with an OmniSTAR Wide Area DGPS Solution. The integrated GPS/DGPS is capable of improving regular GPS accuracies to submeter accuracy by solving for atmospheric delays and weighting of distant base stations. Data were collected and processed while surveying and recorded with the unprocessed depth data while in the field. Position data were collected only during times of good satellite visibility and when OmniSTAR Wide Area DGPS Solution differential corrections were available. Differentially corrected data were acquired for all data obtained during this study and positional accuracy is estimated to be 1 meter ( 3.28 feet) or less.

The PC-based Windows navigational and bathymetric mapping software, Hypack Max, by Coastal Oceanographics, Inc., was used to plan and manage the hydrographic surveys and edit and manage the bathymetric data collected at each lake transect. This software was installed on a portable computer interfaced with the DGPS and surveygrade depth sounder for navigational use. Hypack Max was configured to display and track the vessel position against a background of survey control lines (fig. 3) and later used in the office for processing of the bathymetric data.

\section{Data Processing}

Strict controls on data quality were enforced and no data were included in the final processing that showed systematic roll or vertical boat movement. Relative positions of the DGPS antenna and echosounder transducer were fixed during the survey period to assure accurate horizontal control. Depth to transducer was physically measured, recorded in the field, and used in processing of the data. Raw data were processed in Hypack Max and exported into an X-Y-Z (latitude-longitude-depth) format for importing into a GIS.

Initial processing of the data included the manual removal of spurious data points (outliers) such as singlepoint depths located substantially above or below the general lake-bottom trend, zero depths, or data that showed roll or vertical boat movement (fig. 4). Outliers were generally the result of submerged debris or gas bubbles in the water column. Outliers were visually identified, tagged for deletion, and removed before additional data processing. The resultant data were then corrected for sound velocity by applying the profile data to the raw depth data collected during the survey. Depth from the lake surface to the active face of the transducer was added to the sound-velocity-corrected depths to calculate depth below water surface.

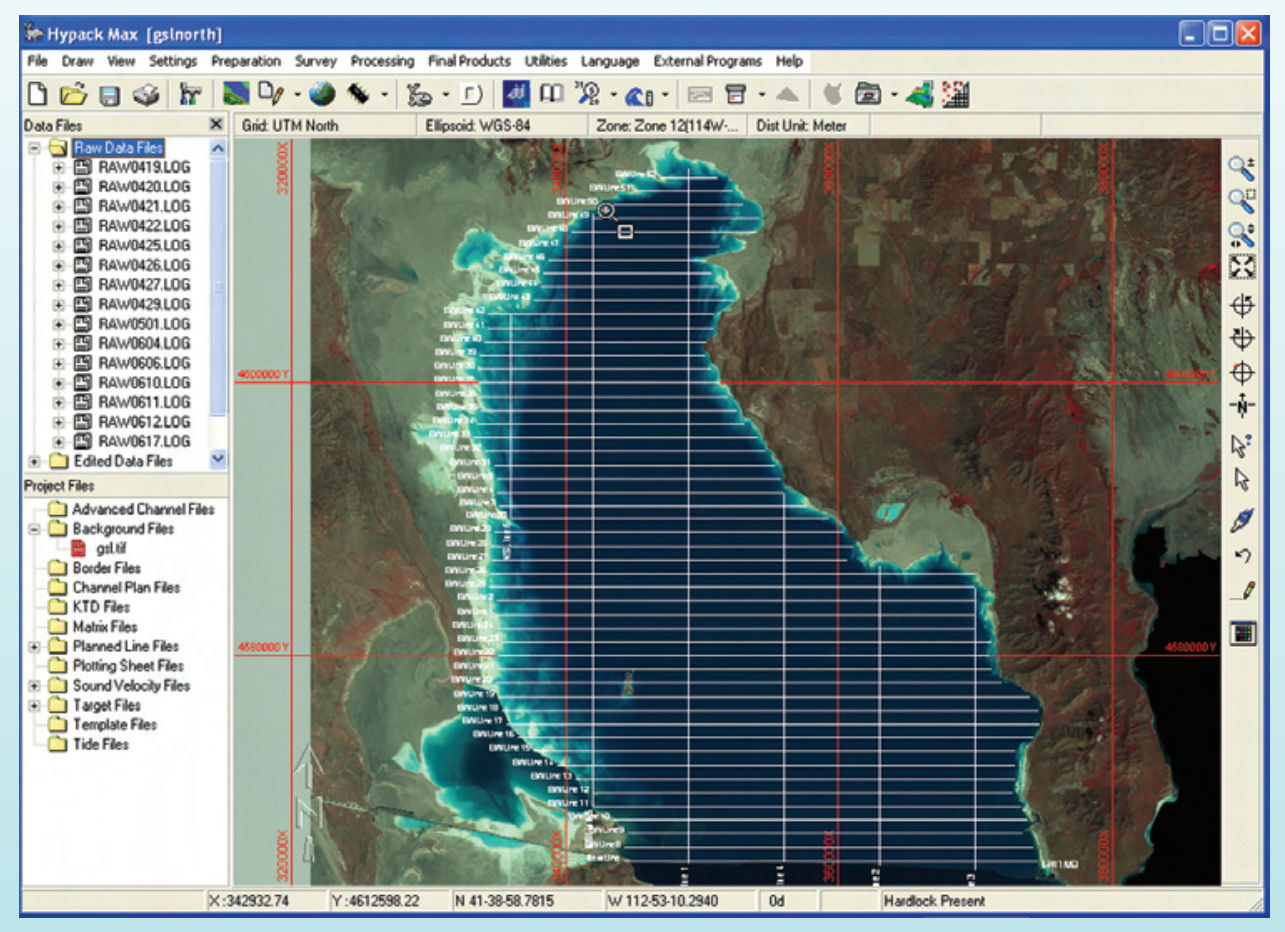

Figure 3. Navigation screen used in survey control of north part of Great Salt Lake, Utah. 
To maximize the amount of depth information acquired during this investigation, depth data were recorded at a frequency of 10 hertz. Differentially corrected positional data were recorded at a frequency of 1 hertz. As a result, about three to five depth measurements were recorded for every meter of survey line depending on actual vessel speed. About 5.2 million discrete depth measurements were initially collected along more than 765 miles $(1,230$ kilometers) of survey transects and processed during this survey. To remove minor bottom-surface variations, an average depth for the lake bottom was calculated every 16 feet ( 5 meters) along each processed survey line, and the averaged depth below lake surface was used in defining the bathymetric surface of the lake. The Behrens Trench (Baskin and Turner, 2006) and other small bottom features were excluded from the map and subsequent calculations of area and volume due to the amount of data necessary to adequately define their structure. Approximately 240,000 averaged depth measurements were calculated and used in the final data analysis.

Depth and location data in an X-Y-Z format were imported into the ArcGIS GIS software package for additional processing. Daily average water-surface altitude data (based on the USGS recorded water-surface altitude) were used to adjust the processed depth-below-water-surface values to altitude. Corrected depth was subtracted from the daily average water-surface altitude for the day the original data were collected to provide lake-bottom altitude along the surveyed transects.

Areas of the lake unavailable for survey because of physical barriers or shallow conditions were digitized from USGS 1:24,000 digital line graphs at a scale of about 1:5,000. These contours ranged from the 4,194-foot (1,278-meter) contour through the 4,200-foot $(1,280$ meter) contour and included all areas of Great Salt Lake north of the Union Pacific railroad causeway. These digi-

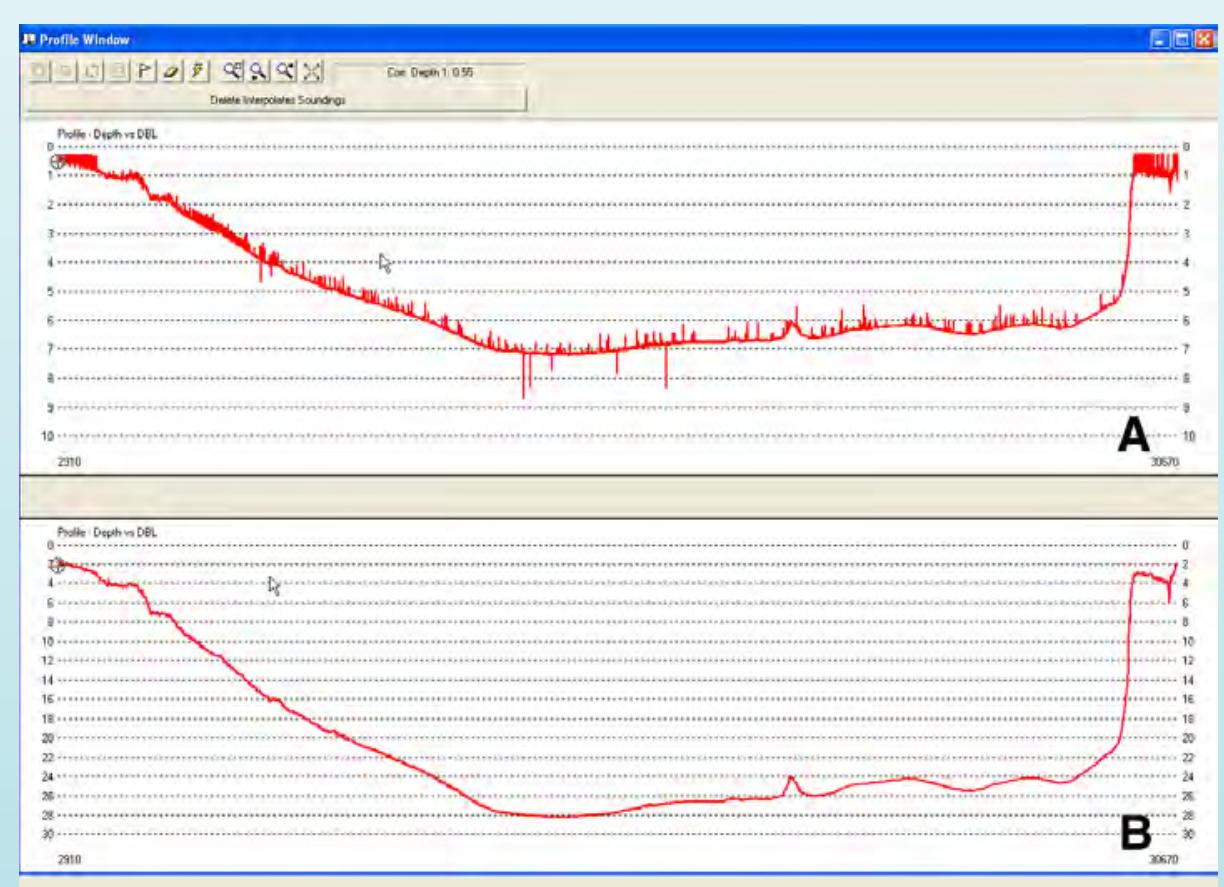

tized contours were incorporated into the bathymetric data set as fixed data contours and used in the calculation of area and volume.

\section{Generation of Bathymetric Surface}

The data points defining the bottom surface of the lake were compiled into a single data file, combined with the digitized contours, and processed into a triangulated irregular network for contour generation and subsequent calculations of area and volume. A triangulated irregular network is defined as a set of adjacent, nonoverlapping triangles computed from irregularly spaced points with $\mathrm{x}, \mathrm{y}$ coordinates and $\mathrm{z}$ values. The triangulated-irregularnetwork model stores the topological relations between triangles and their adjacent neighbors; for example, which points define each triangle and which triangles are adjacent to each other (Environmental Systems Research Institute, Inc., 2004). Each of these triangles has a surface area and an average depth. The triangulated-irregular-network contouring function interpolates straight lines across each triangle that span the contour value by using linear interpolation between the edge endpoints to determine where the contour crosses the face.

The contoured lake-bottom surface for Great Salt Lake was originally computed in 0.5 -foot intervals from altitudes of 4,167 feet (1,270 meters) to 4,200 feet (1,280 meters) and subsequently used as a guide for contouring of the lake-bottom bathymetric surface. As a result of the spacing and orientation of the survey transects, the computer-interpolated contour lines were problematic in areas of high relief. The computer-contoured data were examined and manually recontoured in areas of high relief, primarily those areas bordering the east edge of the basin. The resultant contours were mapped and published in Baskin and Turner (2006) (fig. 5). The interpreted contour data from Baskin and Turner (2006) are used as the basis for the calculation of area and volume in this report.

\section{Calculations of Area and Volume}

Area and volume were calculated with the 3-D surface analysis package in ArcGIS 9.1 (Environmental Systems Research Institute, Inc., 2004). For each altitude, the triangulated irregular network is examined to determine the area and volume of each triangle contained within the limits of that particular altitude. The sum of these triangles is used for the output of area and volume. Output from the calculations of area and volume was tabled and converted to acres and acre-feet for use in this report (table 1).

Values contained in table 1 are for areas of Great Salt Lake north of the Union Pacific railroad causeway, including areas of impoundment near the southwest and

Figure 4. Example survey transect before $(A)$ and after $(B)$ removal of outliers, north part of Great Salt Lake, Utah. 


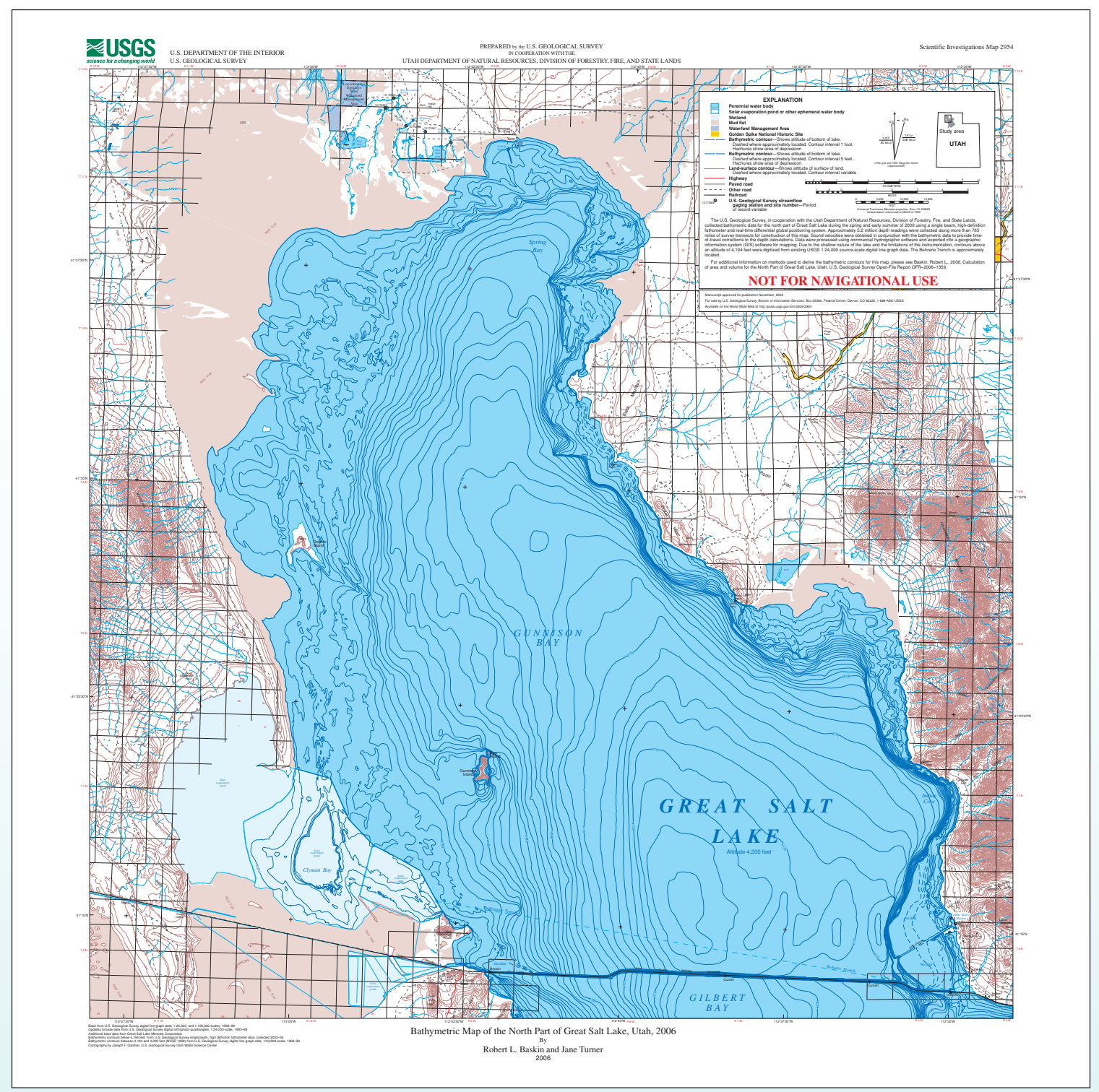

Figure 5. Bathymetric map of the north part of Great Salt Lake, Utah (Baskin and Turner, 2006).

southeast corners of the lake up to the 4,200 -foot contour (fig. 2). The 4,200-foot (1,280-meter) contour digitized from USGS 1:24,000-scale topographic maps was used to limit the north part of the Great Salt Lake triangulated irregular network such that interpolation could not occur outside of that contour. The triangulated irregular network incorporated the vertices of the 4,194 to 4,200 -foot $(1,278$ to 1,280 -meter) contours as additional points.

Calculations of area and volume for the north part of Great Salt Lake show a maximum area of about 385,000 acres (1,560 square kilometers) and a maximum volume of about 5,693,000 acre-feet (about 7 cubic kilometers) at a water-surface altitude of 4,200 feet (1,280 meters). The minimum natural water-surface altitude of the north part of Great Salt Lake is just below 4,167 feet (1,270 meters) in the area just north of the Union Pacific railroad causeway halfway between Saline and the western edge of the lake. The north part of Great Salt Lake generally grades gradually to the west and north and is bounded by steep scarps along its eastern border. Calculations for area and volume are based on a low altitude of 4,167 feet (1,270 meters) to a high altitude of 4,200 feet (1,280 meters).

\section{Summary}

The U.S. Geological Survey, in cooperation with the Utah Department of Natural Resources, Division of Forestry, Fire, and State Lands, collected bathymetric data for the north part of Great Salt Lake during the spring and early summer of 2006 using a single-beam, high-definition fathometer and real-time differential global positioning system. About 5.2 million depth measurements were collected along more than 765 miles (1,230 kilometers) of survey transects. Sound-velocity profiles were obtained in conjunction with the bathymetric data to provide time-of-travel corrections to the depth calculations. Data were processed with commercial hydrographic software and exported into geographic information system (GIS) software for mapping and calculation of area and volume. Data collection methods and quality-control restrictions were identical to those used for generation of the bathymetric map for the south 
part of Great Salt Lake (Baskin and Allen, 2005) and the resulting south part area/volume table (Baskin, 2005).

Area and volume values were calculated for areas of Great Salt Lake north of the Union Pacific railroad causeway, including areas of impoundment near the southwest and southeast corners of the lake up to the 4,200-foot contour (fig. 2). The Behrens Trench and other small bottom features were excluded from the map and subsequent calculation of area and volume due to the amount of data necessary to adequately define their structure. The 4,200foot (1,280-meter) contour digitized from USGS 1:24,000scale quadrangle maps was used to limit the north part of the Great Salt Lake triangulated irregular network such that interpolation could not occur outside of that contour. The triangulated irregular network incorporated the vertices of the 4,194 to 4,200 -foot (1,278 to 1,280-meter) contours as additional points.

Area and volume calculations show a maximum area of about 385,000 acres (1,560 square kilometers) and a maximum volume of about 5,693,000 acre-feet (about 7 cubic kilometers) at a water-surface altitude of 4,200 feet $(1,280$ meters). Minimum natural water-surface altitude of the north part of Great Salt Lake is just below 4,167 feet $(1,270$ meters) in the area just north of the Union Pacific railroad causeway halfway between Saline and the western edge of the lake.

\section{References Cited}

Baskin, R.L., 2005, Calculation of area and volume for the south part of Great Salt Lake, Utah: U.S. Geological Survey OpenFile Report 2005-1327, accessed 08/16/06 at http://pubs.usgs. gov/of/2005/1327/

Baskin, R.L., and Allen, D.V., 2005, Bathymetric map of the south part of Great Salt Lake, Utah: U.S. Geological Survey Scientific Investigations Map 2894, accessed 08/16/06 at http://pubs.usgs.gov/sim/2005/2894/

Baskin, R.L., and Turner, J., 2006, Bathymetric map of the north part of Great Salt Lake, Utah: U.S. Geological Survey Scientific Investigations Map 2006-2954.

Environmental Systems Research Institute, Inc., 2004, ArcToolbox: About surfaces and surface models: ArcGIS 9.0 Desktop Help, accessed June 2005 at http://webhelp.esri.com/arcgisdesktop/9.1

Table 1. Water-surface altitude, area, and volume of north part of Great Salt Lake, Utah

[Values calculated for the area of Great Salt Lake north of the Union Pacific railroad causeway]

\begin{tabular}{|c|c|c|}
\hline $\begin{array}{l}\text { Water-surface } \\
\text { altitude } \\
\text { (in feet) }\end{array}$ & $\begin{array}{c}\text { Area } \\
\text { (acres) }\end{array}$ & $\begin{array}{c}\text { Volume } \\
\text { (acre-feet) }\end{array}$ \\
\hline $4,167.0$ & 2,141 & 1 \\
\hline $4,167.5$ & 4,658 & 1,658 \\
\hline $4,168.0$ & 8,546 & 4,827 \\
\hline $4,168.5$ & 11,891 & 9,906 \\
\hline $4,169.0$ & 19,698 & 16,837 \\
\hline $4,169.5$ & 24,685 & 27,891 \\
\hline $4,170.0$ & 33,316 & 41,687 \\
\hline $4,170.5$ & 38,786 & 59,708 \\
\hline $4,171.0$ & 44,522 & 80,518 \\
\hline $4,171.5$ & 49,697 & 104,298 \\
\hline $4,172.0$ & 54,068 & 130,234 \\
\hline $4,172.5$ & 58,839 & 158,588 \\
\hline $4,173.0$ & 63,216 & 189,095 \\
\hline $4,173.5$ & 68,795 & 222,170 \\
\hline $4,174.0$ & 74,243 & 257,922 \\
\hline $4,174.5$ & 80,060 & 296,521 \\
\hline $4,175.0$ & 86,040 & 338,033 \\
\hline $4,175.5$ & 91,396 & 382,420 \\
\hline $4,176.0$ & 96,949 & 429,491 \\
\hline $4,176.5$ & 102,195 & 479,375 \\
\hline $4,177.0$ & 107,263 & 531,729 \\
\hline $4,177.5$ & 111,222 & 586,350 \\
\hline $4,178.0$ & 116,640 & 643,012 \\
\hline
\end{tabular}

\begin{tabular}{|c|c|c|}
\hline $\begin{array}{l}\text { Water-surface } \\
\text { altitude } \\
\text { (in feet) })^{1}\end{array}$ & $\begin{array}{c}\text { Area } \\
\text { (acres) }\end{array}$ & $\begin{array}{l}\text { Volume } \\
\text { (acre-feet) }\end{array}$ \\
\hline $4,178.5$ & 121,381 & 702,497 \\
\hline $4,179.0$ & 127,179 & 764,476 \\
\hline $4,179.5$ & 132,215 & 829,308 \\
\hline $4,180.0$ & 138,428 & 896,759 \\
\hline $4,180.5$ & 143,029 & 967,108 \\
\hline $4,181.0$ & 150,430 & $1,039,843$ \\
\hline $4,181.5$ & 154,836 & $1,116,148$ \\
\hline $4,182.0$ & 159,824 & $1,194,723$ \\
\hline $4,182.5$ & 164,868 & $1,282,671$ \\
\hline $4,183.0$ & 171,609 & $1,359,241$ \\
\hline $4,183.5$ & 175,809 & $1,446,093$ \\
\hline $4,184.0$ & 180,028 & $1,535,052$ \\
\hline $4,184.5$ & 184,657 & $1,626,337$ \\
\hline $4,185.0$ & 188,996 & $1,719,742$ \\
\hline $4,185.5$ & 193,547 & $1,815,544$ \\
\hline $4,186.0$ & 197,773 & $1,913,357$ \\
\hline $4,186.5$ & 202,476 & $2,013,589$ \\
\hline $4,187.0$ & 206,743 & $2,115,881$ \\
\hline $4,187.5$ & 210,552 & $2,220,286$ \\
\hline $4,188.0$ & 214,171 & $2,326,460$ \\
\hline $4,188.5$ & 217,374 & $2,434,351$ \\
\hline $4,189.0$ & 220,662 & $2,543,854$ \\
\hline $4,189.5$ & 224,044 & $2,655,035$ \\
\hline
\end{tabular}

\begin{tabular}{ccc}
$\begin{array}{c}\text { Water-surface } \\
\text { altitude } \\
\text { (in feet) }\end{array}$ & $\begin{array}{c}\text { Area } \\
\text { (acres) }\end{array}$ & $\begin{array}{c}\text { Volume } \\
\text { (acre-feet) }\end{array}$ \\
\hline $4,190.0$ & 227,516 & $2,767,920$ \\
$4,190.5$ & 231,043 & $2,882,582$ \\
$4,191.0$ & 234,973 & $2,998,990$ \\
$4,191.5$ & 239,695 & $3,117,654$ \\
$4,192.0$ & 245,098 & $3,238,699$ \\
$4,192.5$ & 249,516 & $3,362,349$ \\
$4,193.0$ & 255,045 & $3,488,231$ \\
$4,193.5$ & 259,429 & $3,616,850$ \\
$4,194.0$ & 264,597 & $3,747,660$ \\
$4,194.5$ & 269,214 & $3,881,097$ \\
$4,195.0$ & 285,934 & $4,016,938$ \\
\hline $4,195.5$ & 292,701 & $4,161,596$ \\
\hline $4,196.0$ & 306,649 & $4,309,643$ \\
$4,196.5$ & 313,915 & $4,464,768$ \\
$4,197.0$ & 321,569 & $4,623,623$ \\
$4,197.5$ & 335,497 & $4,789,829$ \\
$4,198.0$ & 341,895 & $4,959,165$ \\
$4,198.5$ & 356,685 & $5,135,356$ \\
$4,199.0$ & 365,556 & $5,315,903$ \\
$4,199.5$ & 377,427 & $5,502,856$ \\
$4,200.0$ & 384,580 & $5,693,352$ \\
\hline 1 A1itr & \\
\hline 4 &
\end{tabular}

${ }^{1}$ Altitude referenced to National Geodetic Vertical Datum of 1929 (NGVD 29). 